\title{
Variation in the Onset of Flowering of Summer Squash as a Function of Days and Heat Units
}

\author{
D.S. NeSmith ${ }^{1}$ and G. Hoogenboom ${ }^{2}$ \\ Georgia Station, University of Georgia, Griffin, GA 30223-1797 \\ Additional index words. Cucurbita pepo, flower sex, temperature, crop development
}

\begin{abstract}
The time from sowing to flowering and maturity of summer squash (Cucurbita pepo L.) varies depending on environment. Research was conducted over a 2-year period to assess flowering time of five squash cultivars grown at different locations and times in Georgia representing varying thermal regimes. Heat units (HUs) were calculated using a single equation to determine if this approach could account for a significant proportion of the variability in the time to onset of flowering observed over this range of environments. Depending on the cultivar and flower sex, the number of days to flowering varied as much as 20 days. There were no cultivar differences in overall mean days to first staminate flower; however, there were differences in mean days to first pistillate flower. There were cultivar differences in HUs required for staminate and pistillate flowers. The use of HUs significantly affected the variability in time to flowering as indicated by regression analyses and mean absolute differences between predicted and observed days to flowering.
\end{abstract}

Summer squash (Cucurbita pepo L.) are produced extensively in the southeastern United States for processing and fresh market. In Georgia alone, $>11,000$ ha are grown annually, and planting ranges from early spring through the fall (Mizelle, 1993). This environmental diversity results in variable days to maturity for the crop; thus, it is difficult for growers to plan planting dates to meet predesignated harvest windows. Research is needed on variability in development of squash cultivars produced in different environments. Identifying the environmental variables that strongly influence development may improve production planning.

Temperature is a major environmental variable influencing plant development, and heat units (HUs) or growing degree days are used extensively to normalize time to crop developmental events in response to temperature (Ritchie and NeSmith, 1991). The HU approach is used for a variety of vegetable crops including sweet corn (Zea mays L.), peas (Pisum sativum L.), tomato (Lycopersicon esculentum Mill.), lettuce (Lactuca sativa L.), and cucumber (Cucumis sativus L.) (Arnold, 1959; Boswell, 1929; Logan and Boyland, 1983; Madariaga and Knott, 1951; Perry et al., 1986). Generally, these experiments concentrate on the time between sowing and maturity. For fresh vegetable crops such as cucurbits, harvest maturity is an ambiguous designation and may significantly vary assessment of the time between sowing and maturity. A more finite developmental indicator such as flowering may be more useful (Perry and Wehner, 1990). For this research, it was hypothesized that temperature is the primary environmental determinant of the time from sowing to flowering in summer squash. The objectives of this research were to 1) evaluate the number of days to flowering for several squash cultivars planted at different dates and locations representing varying thermal regimes and 2) determine whether HUs significantly affect the variability in the time to flowering over a range of environments.

Received for publication 29 Apr. 1993. Accepted for publication 20 July 1993. A contribution of the Univ. of Georgia Agriculture Experiment Station, Georgia Station, Griffin. This research was supported by state and Hatch Act funds allocated to the Georgia Agriculture Experiment Station and by grant funds from Asgrow. We gratefully acknowledge the assistance of the Georgia Mountain Experiment Station staff and the Asgrow staff in collecting data. The cost of publishing this paper was defrayed in part by the payment of page charges. Under postal regulations, this paper therefore must be hereby marked advertisement solely to indicate this fact.

${ }^{1}$ Assistant professor, Dept. of Horticulture.

${ }^{2}$ Assistant professor, Dept. of Biological and Agricultural Engineering.

\section{Materials and Methods}

'Dixie', 'Senator', 'Elite', 'Lemondrop', and 'XPH-1671' squash were grown in 12 experiments over a 2-year period to collect data concerning time to flowering. 'Dixie', 'Lemondrop', 'Senator', and 'XPH-1671' are Asgrow lines, and 'Elite' is a Harris Moran line. 'Dixie' and 'XPH-1671' are yellow crook-neck types, 'Lemondrop' is a yellow straight-neck type, and 'Senator' and 'Elite' are zucchini types. This study was conducted at three Georgia locations: Blairsville $\left(34^{\circ} 51^{\prime} \mathrm{N}, 8^{\circ} 56^{\prime} \mathrm{W}, 586 \mathrm{~m}\right.$ elevation); Griffin $\left(33^{\circ} 15^{\prime} \mathrm{N}, 84^{\circ} 16^{\prime} \mathrm{W}, 299\right.$ m elevation); and Tifton $\left(31^{\circ} 29^{\prime} \mathrm{N}, 83^{\circ} 32^{\prime} \mathrm{W}, 113 \mathrm{~m}\right.$ elevation). Table 1 lists the location, dates of sowing, cultivars grown, and mean temperature of each experiment the first 60 days after sowing. The soil types were a Cecil sandy loam (clayey, kaolinitic, thermic Typic Hapludult), a Transylvania clay loam (fine-loamy, mixed, mesic Cumulic Haplumbrept), and a Tifton sandy loam (fine-loamy, siliceous, thermic Plinthic Paleudult) at Griffin, Blairsville, and Tifton, respectively. The experiments used similar cultural practices. Row width was $0.9 \mathrm{~m}$ and in-row plant spacing was $0.6 \mathrm{~m}$. Cultivars

Table 1. Location, dates of sowing, cultivars grown, and mean temperature the first 60 days after sowing for 12 summer squash experiments during 1991 and 1992.

\begin{tabular}{lcccc}
\hline \hline $\begin{array}{c}\text { Expt. } \\
\text { no. }\end{array}$ & Location $^{\text {z }}$ & Sowing dates & Cultivary & $\begin{array}{c}\text { Mean temp. (C) } \\
\text { the first 60 days } \\
\text { after sowing }\end{array}$ \\
\hline 1 & Griffin & 3 Apr. 1991 & D,S,E,L & 19.9 \\
2 & Griffin & 4 June 1991 & D,S,E,L,X & 24.9 \\
3 & Griffin & 12 July 1991 & D,S,E,L,X & 25.1 \\
4 & Griffin & 18 Aug. 1991 & D,S,E,L,X & 20.1 \\
5 & Griffin & 12 Sept. 1991 & D,S,E,L,X & 17.0 \\
6 & Griffin & 6 Apr. 1992 & D,S,E,L,X & 18.2 \\
7 & Griffin & 11 May 1992 & D,S & 22.6 \\
8 & Griffin & 2 June 1992 & D,S,E,L & 24.6 \\
9 & Griffin & 1 Sept. 1992 & D,S,E,L,X & 18.8 \\
10 & Tifton & 13 Aug. 1991 & D,S,E,L,X & 23.8 \\
11 & Blairsville & 23 May 1991 & D,S,L & 22.2 \\
12 & Blairsville & 20 May 1992 & D,S,L & 20.1 \\
\hline
\end{tabular}

${ }^{\mathrm{z}}$ All locations are in Georgia.

${ }^{y}$ Cultivar code is as follows: $\mathrm{D}=$ Dixie, $\mathrm{S}=$ Senator, $\mathrm{E}=$ Elite, $\mathrm{L}=$ Lemondrop, and $\mathrm{X}=\mathrm{XPH}-1671$. 
were grown in three-row plots in a completely randomized block design with three replications. Plot length was $9 \mathrm{~m}$. Squash were hand-seeded with three to four seeds per hill and were thinned to one plant per hill after emergence. Fertilizer applications consisted of $230 \mathrm{~kg} \cdot \mathrm{ha}^{-1}$ of $10 \mathrm{~N}-4.4 \mathrm{P}-8.3 \mathrm{~K}$ preplant incorporated, and 165 $\mathrm{kg} \cdot \mathrm{ha}^{-1}$ of $34 \mathrm{~N}-0 \mathrm{P}-0 \mathrm{~K}$ sidedressed 3 weeks after emergence. Irrigation was used in all experiments to supplement rainfall. Recommended pesticides were used as needed to control weeds and insects. Sample plants were selected in each plot for enumerating flowers for 2 to 3 weeks. For each experiment, 9 to 15 total plants per cultivar ( 3 to 5 plants per replication) were assessed every 2 to 3 days to determine the number of pistillate and staminate flowers present. Only flowers that had opened since the last sample day were counted. Flower petals were removed during each sample interval to facilitate future enumeration. Plants showing symptoms of virus or other abnormalities were eliminated from the analyses.

Cumulative HUs were calculated during the experiments using daily minimum and maximum temperature data recorded near each site. The formula used for calculating HUs was

$$
\mathrm{HU}=\left[\left(\mathrm{T}_{\max }+\mathrm{T}_{\text {min }}\right) / 2\right]-\mathrm{T}_{\text {base }}
$$

where, $\mathrm{T}_{\max }=$ daily maximum temperature, $\mathrm{T}_{\min }=$ daily minimum temperature, and $\mathrm{T}_{\text {base }}=$ base temperature of $8 \mathrm{C}$.

Two additional conditions or constraints were used in the calculation. If $\mathrm{T}_{\min }$ was less than $\mathrm{T}_{\text {base }}$, then it was set equal to $\mathrm{T}_{\text {base }}$. Also, if $\mathrm{T}_{\max }$ exceeded $32 \mathrm{C}$, it was set equal to $32 \mathrm{C}$. The base temperature and the $32 \mathrm{C}$ ceiling temperature were assumed for these calculations based on germination data for several of these cultivars at constant temperatures (NeSmith and Bridges, 1992). The same HU formula was used for all cultivars and experiments.

Statistical analyses involved calculating means and coefficients of variation (cvs) for days and HUs to first flower on a single-plant basis for data from all experiments. Calculations were made for pistillate and staminate flowers separately. Analysis of variance procedures were used to determine cultivar differences in days and HUs to flowering for pistillate and staminate flowers. The overall mean HUs to flowering was used to predict mean flowering dates for each cultivar, and these data were compared to observed data from the various experiments. Regressions of predicted vs. observed days to flowering based on HUs were conducted for each cultivar. Mean absolute differences (MADs) between predicted and observed days to flowering were calculated for real time and HU predictions.

\section{Results and Discussion}

The number of days from sowing to the first flower of staminate and pistillate flowers of summer squash varied considerably (Table 2). Depending on the flower sex, cultivar, and environment, there was as much as a 20-day difference in the number of days from sowing to flowering. All cultivars for a given environment generally flowered within 2 to 5 days of one another.

Overall mean days and HU to first flower, along with cvs, are shown in Table 3. Coefficients of variation were consistently less when using HUs compared to days for both flower types and all cultivars. Overall average number of days to the first staminate flower for the various cultivars was similar; although, the average HUs to first staminate flower differed between 'Dixie' and 'Senator'. Cultivar differences were observed for days and HUs to first pistillate flower. The average HUs to first staminate flower was greater than the average HUs to first pistillate flower for 'Dixie', 'Lemondrop', and 'XPH-1671'. However, the reverse was true for
Table 2. Mean days to first staminate and pistillate flower of five summer squash cultivars grown in 12 experiments. Location and planting dates for each experiment are listed in Table 1.

\begin{tabular}{|c|c|c|c|c|c|}
\hline \multicolumn{3}{|c|}{ Expt. } & \multicolumn{3}{|c|}{ Cultivar } \\
\hline no. & Dixie & Senator & Elite & Lemondrop & XPH-1671 \\
\hline \multicolumn{6}{|c|}{ Staminate flowers } \\
\hline 1 & $49 \mathrm{a}^{\mathrm{z}}$ & $46 \mathrm{c}$ & $46 b$ & $46 \mathrm{bc}$ & --- \\
\hline 2 & $32 \mathrm{f}$ & $36 \mathrm{e}$ & $33 \mathrm{e}$ & $33 \mathrm{e}$ & $33 \mathrm{de}$ \\
\hline 3 & $32 \mathrm{f}$ & $37 \mathrm{e}$ & $33 \mathrm{e}$ & $33 \mathrm{e}$ & $36 \mathrm{~d}$ \\
\hline 4 & $35 \mathrm{e}$ & $37 \mathrm{e}$ & $37 \mathrm{~d}$ & $37 \mathrm{~d}$ & $36 \mathrm{~d}$ \\
\hline 5 & $46 \mathrm{~b}$ & $46 \mathrm{c}$ & $46 \mathrm{~b}$ & $45 \mathrm{c}$ & $46 \mathrm{~b}$ \\
\hline 6 & $50 \mathrm{a}$ & $50 \mathrm{a}$ & $50 \mathrm{a}$ & $51 \mathrm{a}$ & $51 \mathrm{a}$ \\
\hline 7 & $41 \mathrm{c}$ & $42 \mathrm{c}$ & --- & --- & --- \\
\hline 8 & $38 \mathrm{~d}$ & $39 \mathrm{~d}$ & $40 \mathrm{c}$ & $39 \mathrm{~d}$ & --- \\
\hline 9 & $38 \mathrm{~d}$ & $41 \mathrm{c}$ & $41 \mathrm{c}$ & $38 \mathrm{~d}$ & $41 \mathrm{c}$ \\
\hline 10 & $30 \mathrm{~g}$ & $32 \mathrm{f}$ & $35 \mathrm{de}$ & $32 \mathrm{e}$ & $32 \mathrm{e}$ \\
\hline 11 & $35 \mathrm{e}$ & $37 \mathrm{e}$ & --- & $38 \mathrm{~d}$ & --- \\
\hline 12 & $49 \mathrm{a}$ & $48 \mathrm{~b}$ & --- & $48 \mathrm{~b}$ & --- \\
\hline \multicolumn{6}{|c|}{ Pistillate flowers } \\
\hline 1 & $46 \mathrm{a}$ & $44 \mathrm{~b}$ & $44 \mathrm{c}$ & $45 \mathrm{bc}$ & --- \\
\hline 2 & $34 \mathrm{~d}$ & $40 \mathrm{~cd}$ & $36 \mathrm{e}$ & $35 \mathrm{e}$ & $36 \mathrm{c}$ \\
\hline 3 & $31 \mathrm{f}$ & $34 \mathrm{e}$ & $37 \mathrm{de}$ & $31 \mathrm{f}$ & $30 \mathrm{~d}$ \\
\hline 4 & 32 ef & $40 \mathrm{~cd}$ & $37 \mathrm{de}$ & 33 ef & $35 \mathrm{c}$ \\
\hline 5 & $44 \mathrm{~b}$ & $49 \mathrm{a}$ & $48 \mathrm{~b}$ & $43 \mathrm{c}$ & $45 \mathrm{~b}$ \\
\hline 6 & $46 \mathrm{a}$ & $52 \mathrm{a}$ & $52 \mathrm{a}$ & $49 \mathrm{a}$ & $50 \mathrm{a}$ \\
\hline 7 & $39 \mathrm{c}$ & $43 \mathrm{bc}$ & --- & --- & --- \\
\hline 8 & $39 \mathrm{~d}$ & $41 \mathrm{bcd}$ & $40 \mathrm{~d}$ & $40 \mathrm{~d}$ & --- \\
\hline 9 & $33 \mathrm{de}$ & $40 \mathrm{~cd}$ & $37 \mathrm{de}$ & $35 \mathrm{e}$ & $36 \mathrm{c}$ \\
\hline 10 & $29 \mathrm{~g}$ & $33 \mathrm{e}$ & $37 \mathrm{de}$ & $28 \mathrm{~g}$ & $30 \mathrm{~d}$ \\
\hline 11 & $33 \mathrm{de}$ & $38 \mathrm{~d}$ & --- & $34 \mathrm{e}$ & --- \\
\hline 12 & $44 \mathrm{~b}$ & $50 \mathrm{a}$ & --- & $46 \mathrm{~b}$ & --- \\
\hline
\end{tabular}

$\overline{{ }^{z}}$ Values for each flower sex in the same column followed by the same letter are not significantly different at $P \leq 0.05$.

'Senator' and 'Elite'.

The overall mean HU values were used to predict the number of days to the first staminate and pistillate flower for the squash cultivars over the various experiments, and these predicted values were compared to the mean observed values (Fig. 1). Regression equation parameters for predicted vs. observed days to first flower for individual cultivars are listed in Table 4 . The $r^{2}$ values suggest that the HU formula used was better suited for staminate flowers than for pistillate flowers. The use of HUs as opposed to days to predict the onset of flowering resulted in lower MADs between predicted and observed values for staminate and pistillate flowers for all cultivars (Table 5). However, there was little reduction in the MADs for pistillate flowers of 'Elite'.

The data indicate that thermal variations strongly contribute to differences in days to flowering for summer squash. The HU accumulation significantly affected the variability in time from sowing to flowering for squash grown in diverse environments. A single HU model was used in this analysis, and additional models need to be evaluated to determine whether prediction potential can be improved. Perry et al. (1986) tested a number of different methods of determining HU requirements for cucumber harvest. They used cvs as a primary indicator of model suitability. Future research efforts will include such analyses for these squash data. The manipulation of base and ceiling temperatures should produce more useful models for predicting time to the onset of squash flowering.

The varying $\mathrm{HU}$ requirements for squash cultivars suggest the 
Table 3. Means and coefficients of variation for days and heat units (HUs) to first staminate and pistillate flower for five summer squash cultivars planted at various times and locations (See Table 1).

\begin{tabular}{|c|c|c|c|c|}
\hline \multirow[b]{2}{*}{ Cultivar } & \multicolumn{2}{|c|}{ Mean time to first flower } & \multicolumn{2}{|c|}{ Coefficients of variatio } \\
\hline & Days & $\mathrm{HU}^{\mathrm{z}}$ & Days & $\mathrm{H}$ \\
\hline \multicolumn{5}{|c|}{ Staminate flowers } \\
\hline Dixie & $40 \mathrm{a}^{\mathrm{y}}$ & $533 \mathrm{a}$ & 17.5 & \\
\hline Lemondrop & $40 \mathrm{a}$ & $542 \mathrm{ab}$ & 16.1 & 1 \\
\hline Senator & $41 \mathrm{a}$ & $552 \mathrm{~b}$ & 13.0 & 10 \\
\hline Elite & $41 \mathrm{a}$ & $544 \mathrm{ab}$ & 14.2 & 10 \\
\hline XPH-1671 & $42 \mathrm{a}$ & $540 \mathrm{ab}$ & 17.8 & 10 \\
\hline \multicolumn{5}{|c|}{ Pistillate flowers } \\
\hline Dixie & $38 \mathrm{a}$ & $510 \mathrm{a}$ & 16.5 & 12 \\
\hline Lemondrop & $39 \mathrm{ab}$ & $521 \mathrm{a}$ & 17.1 & \\
\hline Senator & $43 \mathrm{~d}$ & $569 \mathrm{~b}$ & 13.3 & 1 \\
\hline Elite & $41 \mathrm{c}$ & $557 \mathrm{~b}$ & 15.5 & \\
\hline XPH-1671 & $40 \mathrm{bc}$ & $518 \mathrm{a}$ & 19.5 & \\
\hline
\end{tabular}

${ }^{\mathrm{z}}$ Heat units (HUs) were calculated using [Eq. 1].

y Values in the same column followed by the same letter are not significantly different at $P \leq 0.05$.

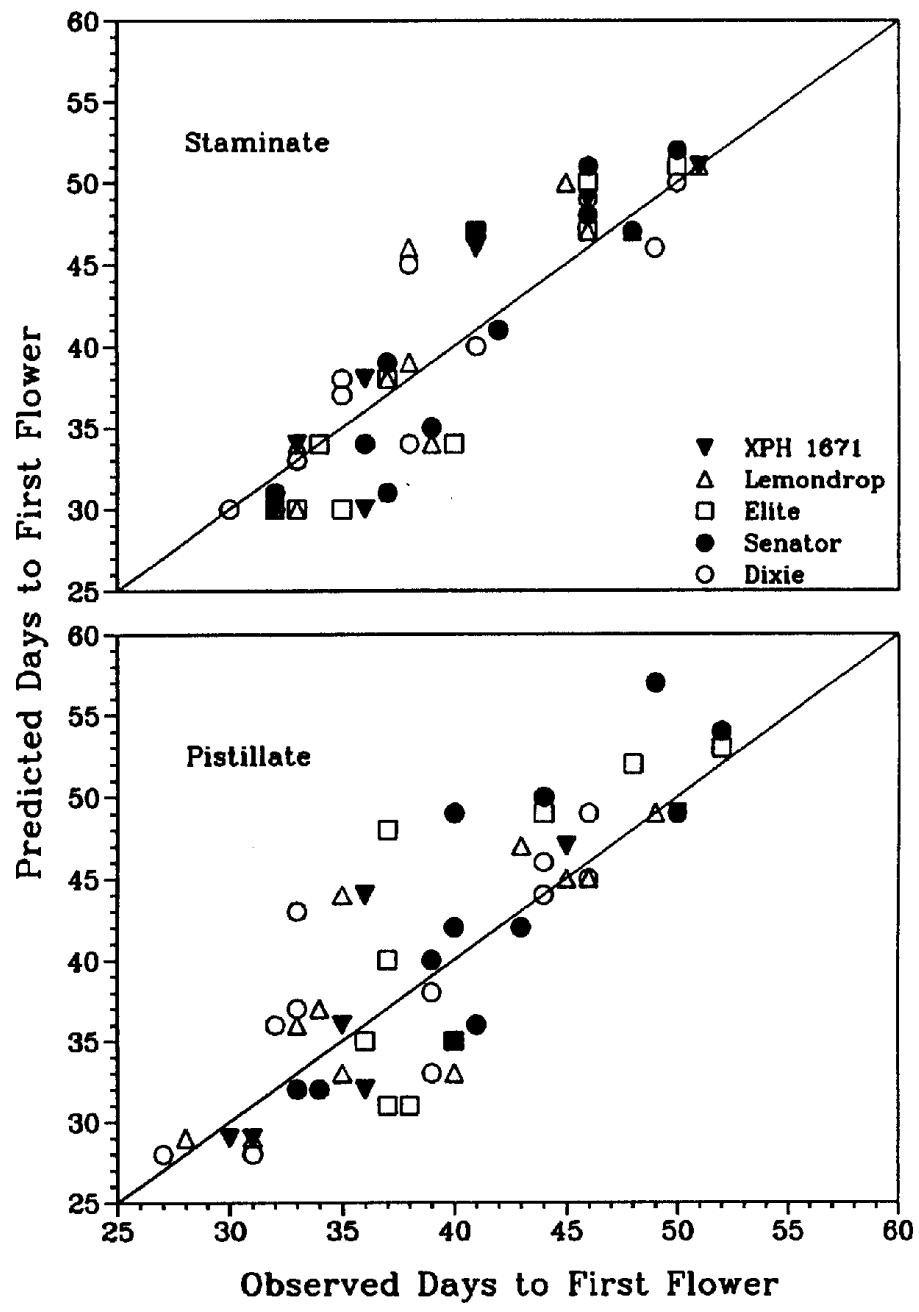

Fig. 1. Predicted number of days from sowing to first staminate and pistillate flower using heat units (HUs) vs. observed days to first flower for five summer squash cultivars grown at different locations and times.

need for a system of classifying cultivars in terms of HUs and developmental events. There may also be cultivar differences in base or ceiling temperatures. However, it is likely that different
Table 4. Regression equation parameters and coefficients of determinations $\left(r^{2}\right)$ for predicted days to flowering using heat units (HUs) vs. field observed days to flowering for five summer squash cultivars.

\begin{tabular}{lccc}
\hline \hline & \multicolumn{2}{c}{ Regression equation parameters ${ }^{\mathrm{z}}$} & \\
\cline { 2 - 3 } Cultivar & \multicolumn{2}{c}{$\mathrm{b}$} & $r^{2}$ \\
\hline & \multicolumn{2}{c}{ Staminate flowers } \\
Dixie & $3.7(5.5)^{\mathrm{y}}$ & $0.91(0.14)$ & 0.818 \\
Lemondrop & $-2.9(7.3)$ & $1.09(0.18)$ & 0.800 \\
Senator & $-9.4(7.6)$ & $1.24(0.18)$ & 0.818 \\
Elite & $-12.4(8.9)$ & $1.31(0.22)$ & 0.836 \\
XPH-1671 & $-6.1(8.6)$ & $1.17(0.21)$ & 0.855 \\
& \multicolumn{2}{c}{ Pistillate flowers } & \\
Dixie & $4.7(7.5)$ & $0.90(0.20)$ & 0.675 \\
Lemondrop & $4.5(7.6)$ & $0.90(0.20)$ & 0.700 \\
Senator & $-9.1(9.9)$ & $1.24(0.23)$ & 0.738 \\
Elite & $-7.7(15.8)$ & $1.20(0.38)$ & 0.584 \\
XPH-1671 & $-1.2(9.0)$ & $1.04(0.23)$ & 0.798 \\
\end{tabular}

${ }^{\mathrm{z}}$ The regression equation was of the form $\mathrm{Y}=\mathrm{a}+\mathrm{bx}$, where $\mathrm{Y}=$ predicted days, $\mathrm{a}=$ intercept, $\mathrm{b}=$ slope, and $\mathrm{x}=$ observed days.

${ }^{y}$ Values in parentheses are the SE of the parameter estimate.

Table 5. Mean absolute difference between predicted and observed days to flowering using average days and heat units (HUs) to predict time to first flower for five summer squash cultivars.

\begin{tabular}{|c|c|c|c|c|}
\hline \multirow[b]{3}{*}{ Cultivar } & \multicolumn{4}{|c|}{ Mean absolute difference } \\
\hline & \multicolumn{2}{|c|}{ Staminate flowers } & \multicolumn{2}{|c|}{ Pistillate flowers } \\
\hline & Days & HU & Days & $\mathrm{HU}$ \\
\hline Dixie & 6.2 & 2.3 & 5.7 & 3.1 \\
\hline Lemondrop & 5.5 & 2.5 & 6.0 & 2.9 \\
\hline Senator & 4.6 & 2.8 & 4.8 & 3.6 \\
\hline Elite & 5.0 & 3.0 & 5.0 & 4.8 \\
\hline XPH-1671 & 6.4 & 2.7 & 6.7 & 2.7 \\
\hline
\end{tabular}

cultivars can be categorized. For example, in this experiment, cultivars generally fell into two classes of $\mathrm{HU}$ requirements for pistillate flowering. Another experiement on squash germination in response to temperature has indicated that base temperatures are likely to be similar, but ceiling or optimum temperatures for development may differ (NeSmith and Bridges, 1992).

The evaluation of HUs from time of sowing to the onset of flowering may cause variability in predictions if only air temperatures are used (Ritchie and NeSmith, 1991). Before emergence, and shortly thereafter depending on the crop, using soil temperatures taken from the depth of seed placement in calculations may improve HU models (Cooper and Law, 1978; Law and Cooper, 1976; Swan et al., 1987). The degree of error associated with the use of air instead of soil temperature in calculating HU requirements largely depends on factors such as location, time of year, and soil management (Ritchie and NeSmith, 1991). Even so, a model using air temperatures is preferable because of the increased availability of the pertinent weather data. Another approach would be to calculate time from crop emergence to flowering. Again, this is less desirable than the use of sowing time due to the added constraint of recording emergence.

A model for predicting the onset of flowering of a crop like summer squash using HUs and historical weather data would be useful. Harvest of this crop generally begins 5 to 7 days after flowering; thus, potential planting dates and predicted flowering dates could be used in planning production and brokering strategies over diverse regions. Percentile estimates for predicted time 
to flowering could aid in risk-management decisions associated with producing this crop. Future research efforts will address these issues as a more reliable HU model is developed.

\section{Literature Cited}

Arnold, C.Y. 1959. The determination and significance of the base temperature in a linear heat unit system. Proc. Amer. Soc. Hort. Sci. 74:430-445.

Boswell, V.R. 1929. Factors influencing yield and quality of peas. Maryland Agr. Expt. Stat. Bul. 306.

Cooper, P.J.M. and L.R. Law. 1978. Enhanced soil temperatures during very early growth and its association with maize development and yield in the Highlands of Kenya. J. Agr. Sci. 89:569-577.

Law, L. R. and P.J.M. Cooper. 1976. The effect and importance of soil temperature in determining the early growth rate and final grain yields of maize in western Kenya. East African Agr. For. J. 41:189-200.

Logan, S.H. and P.B. Boyland. 1983. Calculating heat units via a sine function. J. Amer. Soc. Hort. Sci. 108:977-980.

Madariaga, F.J. and J.E. Knott. 1951. Temperature summations in relation to lettuce growth. Proc. Amer. Soc. Hort. Sci. 58:147-152.

Mizelle, W.O. 1993. Vegetable acreage estimates, Univ. of Georgia, Athens, Coop. Ext. Serv. Bul. Agr. Econ. 93-027.

NeSmith, D.S. and D.C. Bridges. 1992. Summer squash germination in response to temperature. Proc. Natl. Symp. for Stand Establishment in Hort. Crops. Nov. 16-20, Ft. Myers, Fla. p. 15-22.

Perry, K.B., T.C. Wehner, and G.L. Johnson. 1986. Comparison of 14 methods to determine heat unit requirements for cucumber harvest. HortScience 21:419-423.

Perry, K.B. and T.C. Wehner. 1990. Prediction of cucumber harvest date using a heat unit model. HortScience 25:405-406.

Ritchie, J.T. and D.S. NeSmith. 1991. Temperature and crop development, p. 5-29. Modeling plant and soil systems. In: R.J. Hanks and J.T. Ritchie (eds.). Amer. Soc. Agron., Madison, Wis. Monogr. 31.

Swan, J.B., E.C. Schneider, J.F. Moncrief, W.H. Paulson, and A.E. Peterson. 1987. Estimating corn growth, yield, and grain moisture from air growing degree days and residue cover. Agron. J. 79:53-60. 